\title{
THE FOURTH WAVE OF GLOBALIZATION: AN ANALYSIS ON THE IMPACT OF GLOBALIZATION ON SIX DIFFERENT AREAS OF INTEREST
}

\author{
Avani Jhaveri, Ayush Doshi, Darsh Kachhara, Kashvi Makhjia, Oindree Chakraborty and \\ Prithvi Dhirwan
}

Sarla Anil Modi School Of Economics, NMIMS Mumbai

DOI: 10.46609/IJSSER.2020.v05i10.006 URL: https://doi.org/10.46609/IJSSER.2020.v05i10.006

\begin{abstract}
Globalization is a broad term that signifies a primary underlying idea of a progressive integration of societies and economies. The Fourth Wave of Globalization has been unlike the previous ones seen before. It is augmenting a new sector of employment, shouldering a scale of technological innovation never seen before, and enduring the most of a new wave of protectionism, while keeping in mind the original aspects of globalization vis-à-vis trade poverty, and inequality.
\end{abstract}

Keywords: Globalization, Poverty, Inequality, Employment, Economy.

\section{Introduction}

Globalization is a broad term that signifies a primary underlying idea of a progressive integration of societies and economies. New forms of technology, innovation, economic relationships, and social and cultural integration anoint a large range of actors in the form of governments, multi-national corporations, international organizations, factors of production, and the society to drive forward what we consider 'globalisation'. (The World Commission on the Social Dimension of Globalization, 2004)

The Fourth Industrial Revolution, or the Fourth Wave of Globalisation is responsible for not only geopolitical and economic change, but is also ushering in the digitization of social, economic, and political states.

The data used to account for the "fourth wave" of globalisation would be primarily the KOF Globalisation Index (KOFGI) (Dreher, 2006) created in 2006. It covers three main dimensions of globalisation: social integration, economic integration, and political integration. The primary 


\section{International Journal of Social Science and Economic Research}

ISSN: $2455-8834$

Volume:05, Issue:10 "October 2020"

areas of impact of globalisation are six-fold: poverty, income inequality, trade, labour and society, capital movements, and technological innovation.

\begin{tabular}{|c|c|c|c|c|c|c|c|c|}
\hline & $\begin{array}{l}\text { World } \\
\text { KOFGI }\end{array}$ & $\begin{array}{l}\text { East Asia } \\
\text { KOFGI }\end{array}$ & $\begin{array}{l}\text { Europe and } \\
\text { Central Asia } \\
\text { KOFGI }\end{array}$ & $\begin{array}{l}\text { Latin America } \\
\text { and Caribbean } \\
\text { KOFGI }\end{array}$ & $\begin{array}{l}\text { Middle East } \\
\text { and North } \\
\text { Africa KOFGI }\end{array}$ & $\begin{array}{l}\text { North America } \\
\text { KOFGI }\end{array}$ & $\begin{array}{l}\text { South Asia } \\
\text { KOFGI }\end{array}$ & $\begin{array}{l}\text { Sub-Saharan } \\
\text { Africa KOFGI }\end{array}$ \\
\hline 2000 & 52.5 & 50.9 & 65.1 & 52.3 & 53.3 & 68.3 & 38.1 & 40.5 \\
\hline 2001 & 53.3 & 51.8 & 65.9 & 53.4 & 54.0 & 68.7 & 38.8 & 41.1 \\
\hline 2002 & 53.4 & 51.3 & 66.2 & 53.1 & 54.3 & 68.2 & 39.7 & 41.3 \\
\hline 2003 & 54.4 & 52.4 & 67.1 & 54.4 & 55.3 & 68.6 & 40.4 & 42.4 \\
\hline 2004 & 55.5 & 53.0 & 68.3 & 55.4 & 56.9 & 69.1 & 41.7 & 43.5 \\
\hline 2005 & 56.4 & 54.4 & 69.0 & 56.2 & 58.1 & 69.2 & 43.2 & 44.2 \\
\hline 2006 & 57.5 & 55.0 & 70.3 & 57.4 & 59.7 & 69.7 & 45.0 & 45.1 \\
\hline 2007 & 58.8 & 55.9 & 72.1 & 58.6 & 61.0 & 70.4 & 46.5 & 46.2 \\
\hline 2006 & 59.3 & 56.3 & 72.7 & 58.7 & 61.7 & 70.1 & 47.5 & 46.9 \\
\hline 2009 & 59.6 & 56.7 & 72.7 & 58.6 & 62.3 & 70.1 & 47.6 & 47.3 \\
\hline 2010 & 60.1 & 57.4 & 73.2 & 59.1 & 62.8 & 70.0 & 48.7 & 48.1 \\
\hline 2011 & 60.5 & 57.9 & 73.4 & 59.6 & 62.7 & 70.2 & 49.6 & 48.6 \\
\hline 2012 & 60.9 & 58.4 & 73.9 & 59.8 & 62.9 & 70.1 & 49.9 & 49.1 \\
\hline 2013 & 61.2 & 58.7 & 73.9 & 60.1 & 63.1 & 70.3 & 50.0 & 49.6 \\
\hline 2014 & 61.8 & 60.0 & 74.5 & 60.4 & 63.2 & 70.7 & 50.7 & 50.2 \\
\hline 2015 & 61.7 & 60.1 & 74.5 & 60.3 & 62.8 & 70.6 & 50.7 & 50.1 \\
\hline 2016 & 61.9 & 60.5 & 74.8 & 60.4 & 62.7 & 70.9 & 50.8 & 50.2 \\
\hline 2017 & 62.1 & 60.7 & 75.1 & 60.6 & 63.0 & 71.1 & 50.8 & 50.4 \\
\hline P-val & & 0.0 & 0.0 & 0.0 & 0.0 & 0.0 & 0.0 & 0.0 \\
\hline Corr & & 0.986489246 & 0.998285351 & 0.996307472 & 0.984676623 & 0.966567417 & 0.99813844 & 0.996918764 \\
\hline
\end{tabular}

Source: (Gygli, Haelg, Potrafke, \& Sturm, 2019)

The KOFGI has been calculated for the world, and for each country. For simplicity, the World KOFGI has been compared to the KOFGI of major world-regions: East Asia, Europe and Central Asia, Latin America and Caribbean, Middle East and North Africa, North America,

South Asia, and Sub-Saharan Africa. World KOFGI shows no statistically significant difference with the regional KOFGIs, allowing us to use World KOFGI as a proxy variable for all the regions mentioned. The same, however, cannot be said for FDI inflows, which are also used as a measure of globalisation within each region. No single proxy variable can be taken for net FDI inflows in the world and the seven regions.

\section{Poverty}

The number of individuals living under extreme poverty has reduced to $10 \%$ in 2015 from $36 \%$ in 1990. (World Bank). These progressive trends are largely due to the growing economic integration among nations, which has led to increasing productivity of resources worldwide as countries and regions specialise in line with their comparative advantage. 
The Headcount Index is the amount of the population that falls beneath the official poverty level. It is set by taking the entire number of people in a nation who fall below the predetermined income level and dividing this figure by the total population. On carrying out a multivariate analysis for a period of 1981-2017 based on the data from World Bank we found that $95 \%$ of the decrease in the global poverty headcount can be explained by the introduction of world globalisation.

\begin{tabular}{|l|l|}
\hline Global R square & 0.954992308471514 \\
\hline
\end{tabular}

\section{WORLD-globalisation index and poverty headcount}

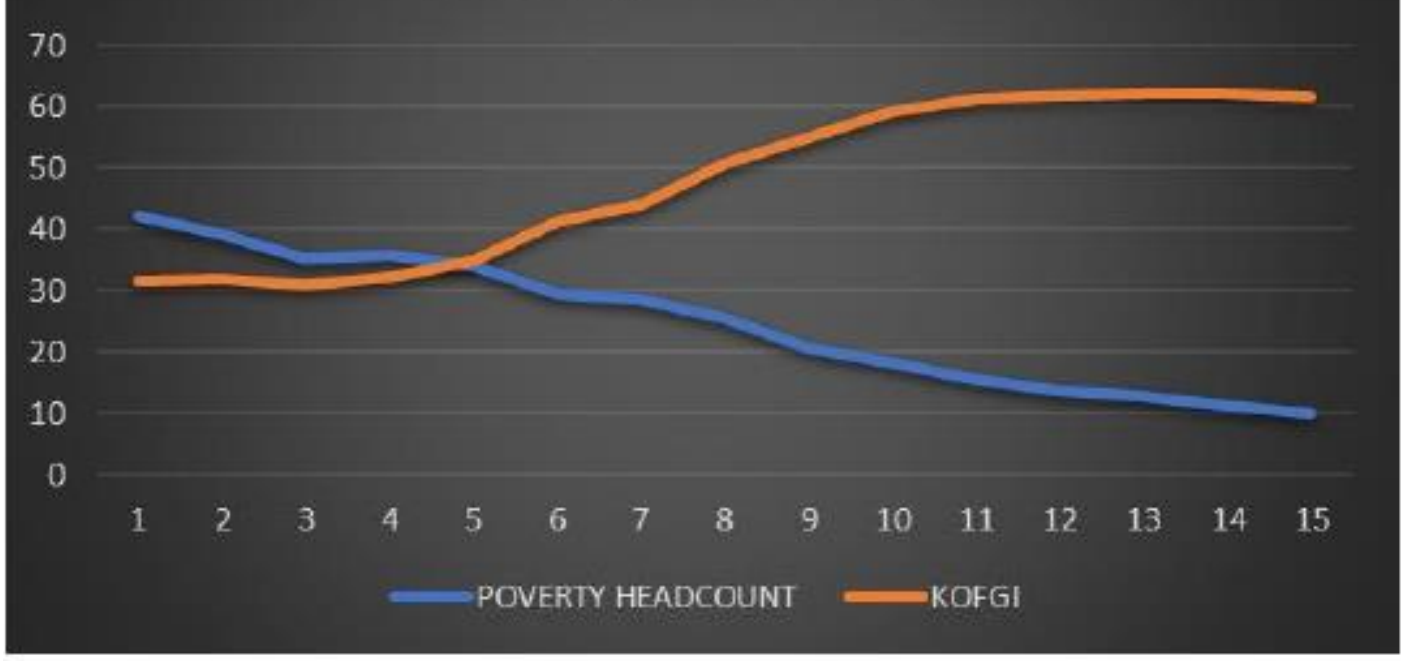

\section{(I) Globalisation reduces poverty}

We have observed that cross border exchange among nations usually benefits the rich and the poor. Supporting the neo liberal theory it had been believed that open economies are more prosperous. An expansion within the trade development and GDP occurs when nations open their economy. A nation's economy is open or experiencing free trade when hindrances like tax or custom obligations are removed, foreign direct investments are available, and this generates employment for citizens.

In countries like China and India, one can see that in 1998 globalization helped reduce extraordinary poverty and made sure that compared to other nations they are not exceedingly worse off. Those individuals living in states of extreme poverty improved their living standard 
International Journal of Social Science and Economic Research

ISSN: 2455-8834

Volume:05, Issue:10 "October 2020"

with the help of the jobs created. China, India, and Vietnam are frequently seen as successful models of a globalized economy. The Poverty headcount in India was last announced at 21.9\% in 2011-12 as compared to $37.2 \%$ in 2004.

\section{(II) Globalization Increases Poverty}

Despite what may be expected, numerous financial experts are unconvinced by the neoliberal view that globalization decreases poverty. Pilger (2001) in his report on Indonesia presents that poverty stays unaltered in that region despite the ventures and investments from worldwide enterprises (e.g. Nike, Reebok, Adidas, Gap etc.). Indonesian specialists and experts are paid just somewhat over US $\$ 1$ daily which is just little over half the living wage. Harrison (2006) finds comparable circumstances in Mexico. The country is a member of North American Free trade Agreement (NAFTA) marked in 1993 with Canada, Mexico, and USA. Trade is usually known to reduce poverty and advantage the poor. However, Harrison (2006) infers that poverty rates in Mexico within the year 2000 were higher than what it had been in the past decades.

In South America, somewhere within the range of 1980 and 1998, Argentina encountered growth and development in the poverty rate, expansion in FDI and level of openness. Thus, showing an inverse relation of poverty to the opening of their economy. This nations poverty rate is relatively higher than in the case of other developing nations.

Increase in poverty after globalisation usually occurs due to increase in the relative wage of skilled workers and technology which is a consequence of the greater integration of the abovementioned nations to the world market. Hence putting the poor or unskilled at a perpetual disadvantage.

\section{Data}

$\mathrm{R}$ squared is the goodness of fit in a linear model or the degree to which the proportion of variance within the $\mathrm{X}$ variable is explained by the $\mathrm{Y}$ variable On taking the KFO globalisation index as our $\mathrm{X}$ or Independent quantity and the poverty headcount ratio of various regions as $\mathrm{Y}$ or the dependent variable we could see that a large portion of a countries poverty rate can be explained by globalisation. 
International Journal of Social Science and Economic Research

ISSN: 2455-8834

Volume:05, Issue:10 "October 2020"

\begin{tabular}{|l|l|}
\hline Region & R Square \\
\hline World (poverty headcount decreased) & 0.954992308471514 \\
\hline China (poverty headcount decreased) & 0.975075531927295 \\
\hline Indonesia (poverty headcount increased) & 0.917184304923234 \\
\hline Mexico (poverty headcount increased) & 0.399185588347466 \\
\hline
\end{tabular}

Supported by the information mentioned within the table above we can safely say that compared to the other nations Mexico includes a lower $r$ square. This means that only $39 \%$ of the poverty headcount in Mexico is explained by globalisation while the remainder might be a mixture of other factors like insufficient foreign investments, depletion or lack of natural resources, drought, facility shortages, etc. We can see there's a negative or inverse relation between globalisation and poverty rates in Mexico while also noticing the degree of globalisation's impact on the poverty headcount is comparatively low.

Thus, we see that various countries respond to globalisation in different ways. Major countries have a positive impact due to globalisation but developing countries like Mexico do not always receive identical benefits. Globalization and poverty are highly correlated. First, inhibitions to exports from developing countries worsen poverty in those countries. Second, careful targeting is important to deal with the poor in several countries who are likely to be negatively impacted or harmed by globalization. Finally, the evidence suggests that counting on trade or foreign investment alone isn't enough to alleviate poverty. The poor needs access to credit, improved infrastructure and therefore the capacity to migrate out of declining sectors into growing or expanding ones to exploit trade reforms.

\section{Income Inequality}

Globalization is widely regarded as a factor increasing income inequality. As far as global inequality is concerned, globalisation rather seems to support income convergence by increasing mean average incomes in EMDCs and underdeveloped nations. Many emerging countries, especially China, have caught up with the developed world during globalisation. The United States, for example, is widely seen as the country that has experienced the most pronounced increase in income inequality, but other advanced and developed nations also report growing divergence between rich and poor.

\section{Global trends: Causes and Consequences}


Figure 1 Between and Within country inequality Theil Index

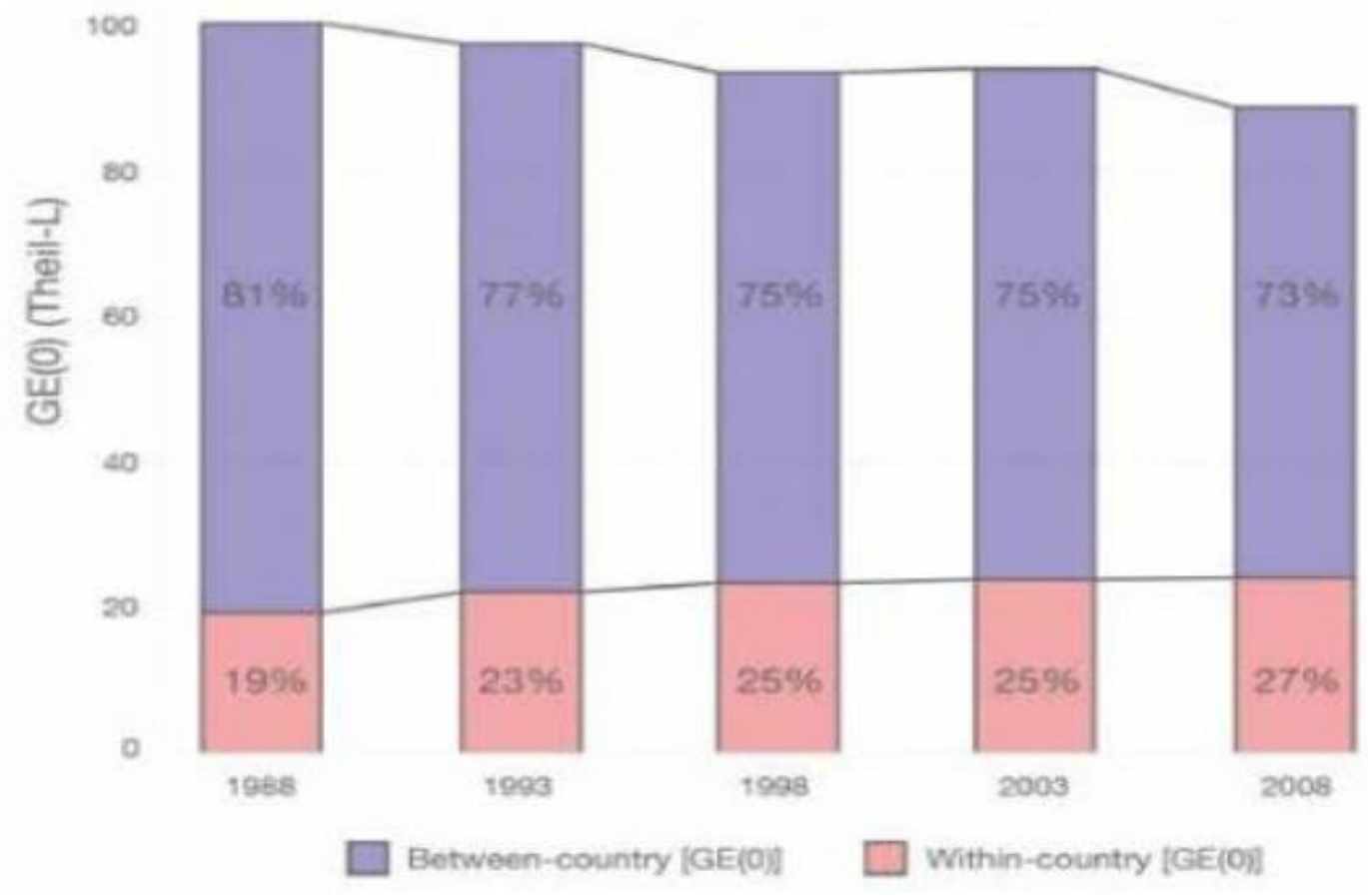

The above graph shows that although between-country inequalities are diminishing, they still vastly outweigh within-country inequalities. The increase in within-country inequality visible throughout the 1980s and 1990s, although significant, has been outpaced by the convergence in average incomes between countries, thus resulting into a reduction in overall global inequality. In advanced economies, the ability of firms to adopt labour saving technologies and off shoring has been an important driver of the decline in manufacturing and rising skill premium thus have created a great divide between the highly skilled and the unskilled, semiskilled workers. At the same time, increased trade flows have lowered income inequality in EMDCs by increasing demand and wages for abundant lower-skilled workers through the Balassa-Samuelson effect. This thus, support the rising inequality within high income advanced economies and declining inequality within developing and low-income countries. 
Figure 2: Global income inequality between countries, 1960-2013

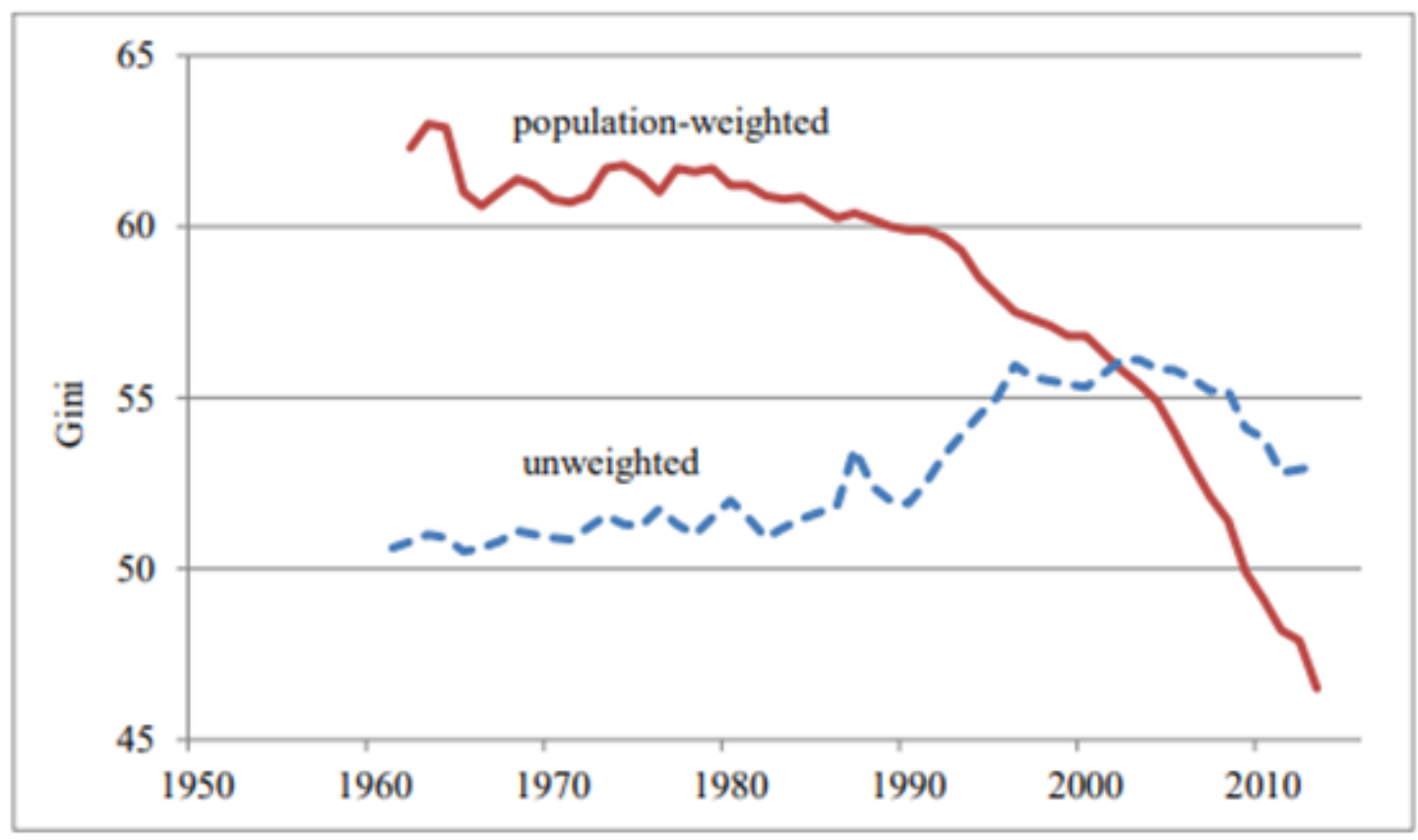

The high level of global inequality reflects sizeable per capita income disparities across countries, which account for around three quarters of global inequality. The GINI and population weighted GINI coefficients of global inequality exhibit a declining trend in the last few decades especially the population weighted GINI in response to rising incomes for those living in China and India, where millions of people have successfully removed their BPL status. As seen above the global economic inequality has been showing a downward trajectory since early 1990s which can be mainly attributed to financial deregulation due to globalization. The onset of globalization and financial deregulation has resulted in movement of financial flows and technology from advanced to underdeveloped and developing nations. This has thus resulted in the overall increase in incomes of the people in such EMDCs due to greater financial inclusion. But the implication here is that the financial institutions in these countries have a major role to play in the process of financial inclusion. Thus, the countries with an organized financial sector like China have been able to equally distribute the effects among all percentiles of income whereas in an unorganized financial sector economy the rich have taken over all the benefits of such financial deregulation which thus has resulted in greater within country inequality. The movement of high technology FDI has also helped improve the skill intensity of the EMDCs thus reducing the gap between them and the high-income countries and thus can lead to long run convergence. 


\section{Figure 3 Income Distribution 1980-2016}

The elephant curve of global inequality and growth, 1980-2016

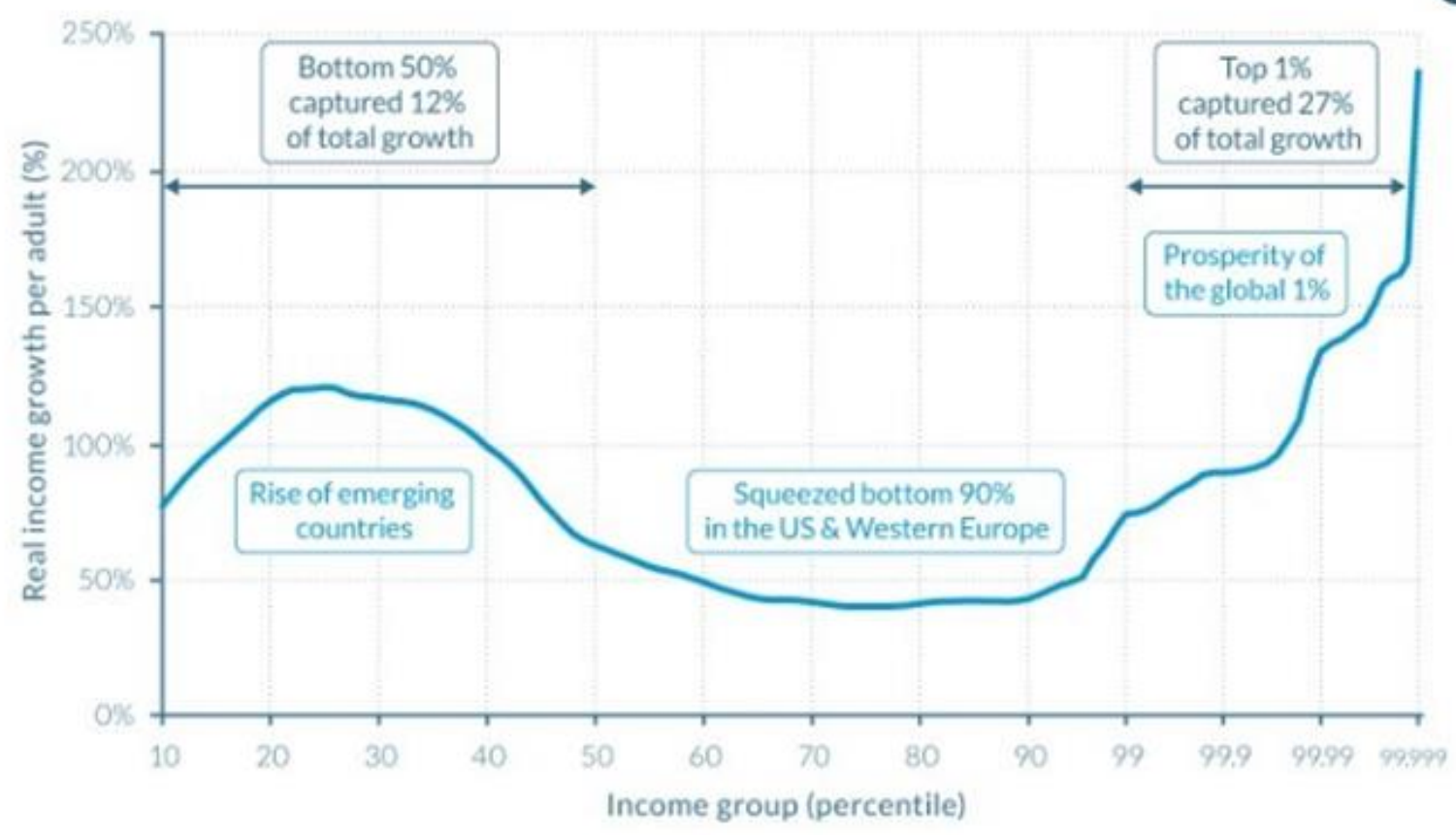

As per Figure 3, changes in real incomes between 1998 and 2008 at various percentiles of the global income distribution show that the largest gains were distributed to the global median income (50th percentile) earners and for the top 1 percent (IMF, 2015). This is in line with the rapid growth of the middle class in many emerging market economies, and the concentration and exponential growth of top earners in advanced economies, respectively. Moreover, income gains rapidly decrease after the 50th percentile and become stagnant around the 80th-90th global percentiles before shooting up for the global top 1 percent (IMF, 2015). The poorest half of the global population has seen its income grow significantly thanks to high growth in Asia (particularly in China and India). However, because of high and rising inequality within countries, the top $1 \%$ richest individuals in the world captured twice as much growth as the bottom 50\% individuals since 1980 (World Inequality Database, 2018). Income growth has been sluggish or even zero for individuals with incomes between the global bottom 50\% and top $1 \%$ groups (World Inequality Database, 2018). This includes all North American and European lower- and middle-income groups.

Global inequality hasn't risen steadily in the past 2 decades. While the global top $1 \%$ income share increased from $16 \%$ in 1980 to $22 \%$ in 2000 , it declined slightly thereafter to $20 \%$. The 
International Journal of Social Science and Economic Research

ISSN: 2455-8834

Volume:05, Issue:10 "October 2020"

income shares of the global bottom 50\% has oscillated around 9\% since 1980 (World Inequality Database, 2018). The trend breaks after 2000 is due to a reduction in between-country average income inequality, as within-country inequality has continued to increase.

\section{Convergence?}

Economic reform and the take-off of the East Asia economies like Japan, South Korea, etc was the initial trigger for the reversal of the long rising trend in inter-country income inequality. The pick-up of growth in China was an especially important factor given the large weight of the country's population which has substantially decreased the population weighted GINI since the early 1990s. The decline in inter-country inequality accelerated after 1990, and especially 2000, as further progress on economic reforms and economic liberalization led to rising growth in a broader group of developing economies, including other highly populated countries such as India. The positive gap between average growth in emerging market and developing economies and advanced economies widened further after the global financial crisis in 2007 as the former group being the epicentre of the crisis, their growth was much adversely affected than the latter group. Convergence in mean incomes between high income advanced nations like USA, France, etc and EMDCs like China, India until now has been driven predominantly by Asian emerging economies, but continued convergence is only possible if regions like Africa and Latin America improve their growth performance. However, with overall growth in emerging market and developing economies declining post the Global Financial Crisis, the pace of convergence could be slower than in the 1990-2012 period.

\section{Trade}

\section{Correlation between trade and globalisation}

Over The last century the most important development this world has seen was the nation countries all over the world have integrating to form a single global economic system. This integration, or so to say globalisation has culminated into remarkable growth of trade within the nation. On running a simple regression test between globalisation, for which we used the $\mathrm{KOF}$ globalisation index and volume of trade, the $\mathrm{R}^{\wedge} 2$ was found to be 0.98 , from which can be inferred the strong co-dependence between the two variables. 


\section{Over the Years}

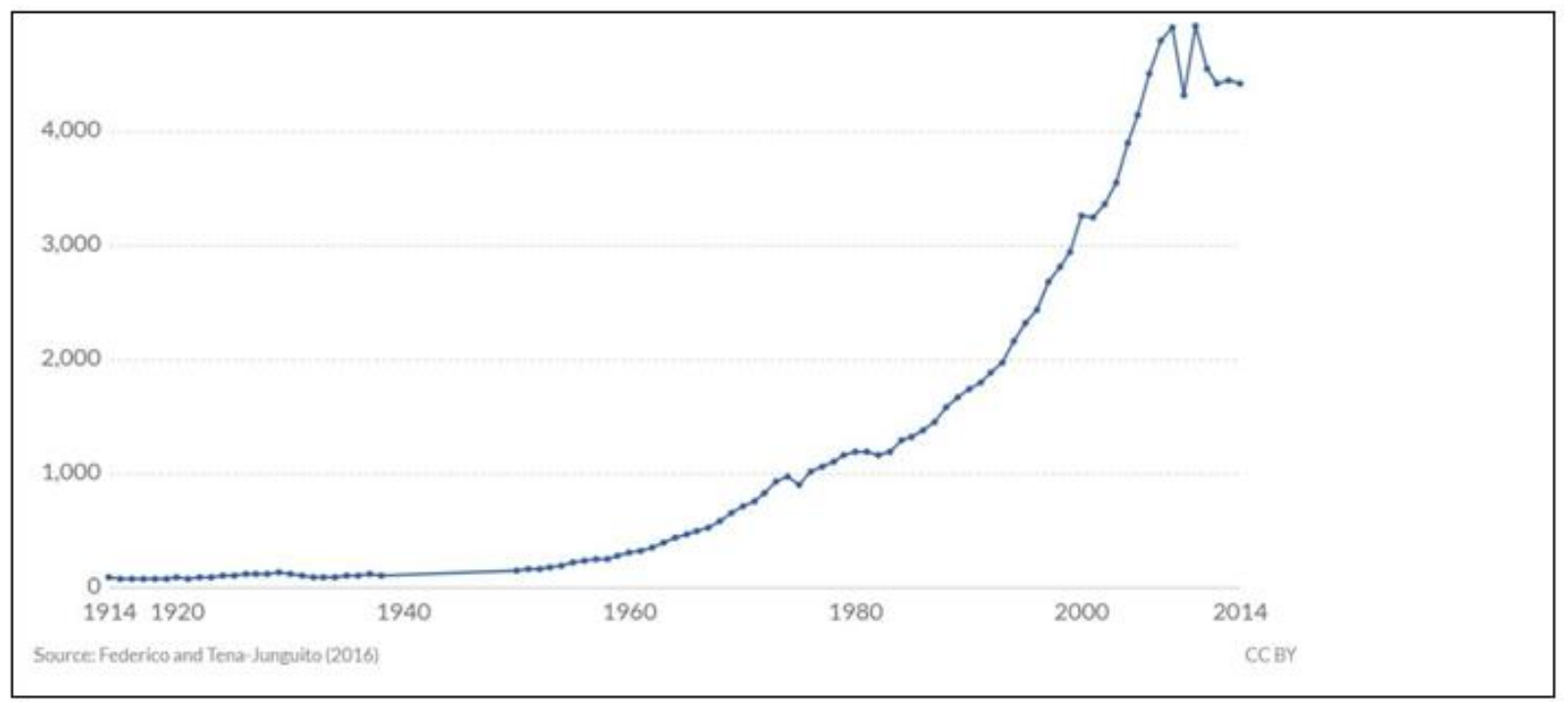

The following linear graph indicates the growth of trade from 1914 through to 2014, and as for what can be seen trade exports have grown a total of 40 times over the period. Trade today makes up for over $25 \%$ of a countries' GDP as compared to $10 \%$ of the total GDP about 2 centuries ago. This move towards freer trade and globalisation can be considered a gradual process as was seen through the two waves of globalisation. The first one was more focussed on mercantilist trade tactics, usually carried out by colonisers whereas the second wave was towards a freer market- though it collapsed following the onset of the world wars. As studied by Eaton and Kurtom (2002), distance and volume of trade are negatively related, and with improvement in technology which revolutionised travel- leading to lower transmission costs, the world became a smaller place and hence trade exponentially grew following this. Various developing, impoverished states start exporting primary goods and gradually grow. And as self-dependency started increasing, there rising trends seen among these countries (Esteban Ortiz-Ospina, 2014) of bilateral and south-south trade as countries moved towards symbiotically growing and developing, as north-south trade became less relevant as seen from the fact that in 2010 , they accounted for only $25 \%$ of the total agreements . another example to put light on this could be the fact that over $48 \%$ of exports from India go to Asian nations. 


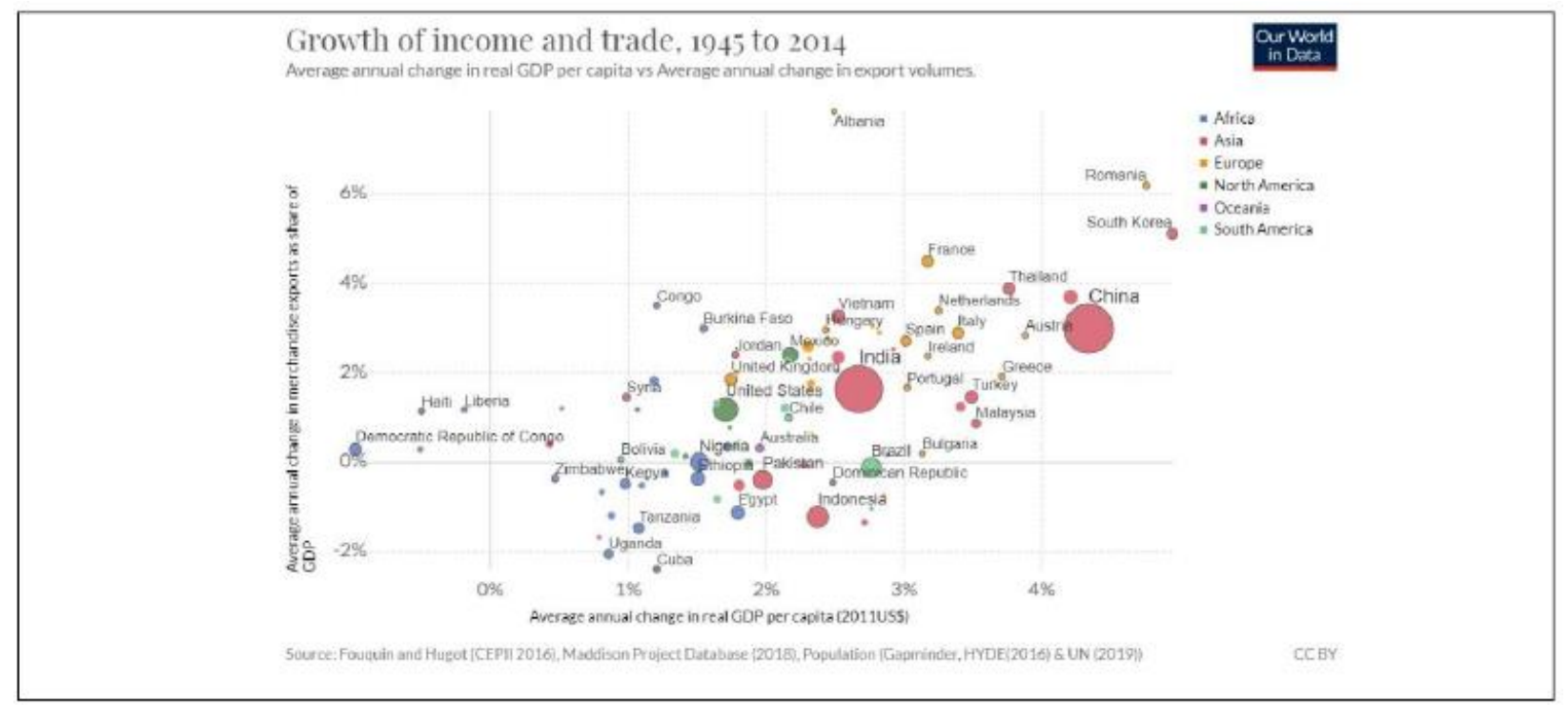

Such change in trade patterns prompted move towards intra-industry trade from interindustry. Bringing about a new age of specialisation and rapid growth in technology. This was followed by increased employment and efficiency in domestic markets as well. As countries grew and become more advanced, trade started becoming a weapon to display dominance over other states. Countries that are global influence reap the benefit of higher exports. A point estimate made shows that $1 \%$ net increase in soft power can lead to trade increasing by $0.8 \%$ ( (Rose, 2015). Like in case of the U.S, they have successfully been able to maintain their status as a super power by making nations dependant on their exports, even if it may come at the cost of, they countries' domestic development- an example being that of Jamaica.

\section{The Tiger Economies}

A very good example of the true result of globalisation is reflected in the success stories of the tiger economies, referring to a group of east Asian nations that have experienced exponential growth backed by their export industry, specifically referring to South Korea, japan, China and Indonesia. All these nations started growing post the second world war from a very disadvantageous spot - namely the great famine in China, the Atomic blast in japan, And loss of their fertile lands to the north in case of South Korea. However with a new age of technological development, these countries mobilise their then only asset- labour, to export ancillary and primary parts of machine at lower costs and successfully take over the market. And as these exports help in refuelling their economy- countries like Korea and japan invest more in their research and development and bring about new waves of innovation and technology for example the Mp3 player or smartphones. This has led to a lot of trade co- 


\section{International Journal of Social Science and Economic Research}

ISSN: $2455-8834$

Volume:05, Issue:10 "October 2020"

operation among these nations which has extended beyond just consumer goods. This can be seen from how Japan, South Korea, China make up some of the biggest investors in ASEAN nations like Indonesia or how Indonesia procured 2 submarines with the help of South Korea. Historically speaking, Japan and Korea have had strained diplomatic relations rooting from the Japanese occupation; however today these two nations collectively dominate the microchip industry (Heekyong Yang, 2019). Today a 'Made in Japan' tag is among the top 10 most reputed tags in the world (Strauss, 2017). The same can be said for China, which has become a manufacturing hub for the world. China has gone head-to-head with the United States with regards their global dominance. Their influence can be seen from instances like how Uighur persecution has not been protested against by most Islamic nations owing to the fact that most of these nations import their defence equipment from China and they keep expanding through initiatives like their magnum opus- the belt road initiative that aims to connect all of the major port routes around the word.

\section{Recent trends}

Recent trends, however have been going south. Trade intensity, has been reducing in recent years as nations choose to consume their own products (Susan Lund, 2019). Another argument that can support these trends could also be the rising awareness among states about the effects that failure in one nation could have on other countries in such an integrated global system, as was learnt from experience in the 2008-9 world recession. Moreover there has been a rise in nationalistic sentiments among the people in general which has finally culminated in to events like a full-blown trade war between China and the US.

\section{Labour and Society}

The First Wave of Globalisation was driven by innovations in the sphere of transport and communications. Transport costs fell, tariff barriers reduced, and trade expanded, with landintensive primary commodities being exchanged for manufactures. The Second Wave came after the retreat into nationalism, and saw a surge in reduction of trade barriers, and reduction of transportation costs. Incomes of rich economies rose faster due to economies of scale and economies of agglomeration. The Third Wave saw many developing countries break into the global market due to substantial capital movements that set up long-term supply chains.

The Fourth Wave is set on the shoulders of advancement in technology that can significantly impact global productivity. This has the potential to have a much larger impact on services than other sectors. (Ho, 2019).

Considering the impact of the fourth wave of globalisation on the service sector, it is only apt 


\section{International Journal of Social Science and Economic Research}

ISSN: $2455-8834$

Volume:05, Issue:10 "October 2020"

to check for the validity of the same. It is observed that the World KOFGI can explain 90-94\% of the employment in the service sector, while FDI inflows can only explain $44-42 \%$ of service employment. This could show that there is much more to do with globalisation increasing the productivity of the sector using tools, than capital inflows. This is unlike the previous wave of globalisation. Nonetheless, the premise cannot be rejected and globalisation can be said to have helped increase the service sector employment.

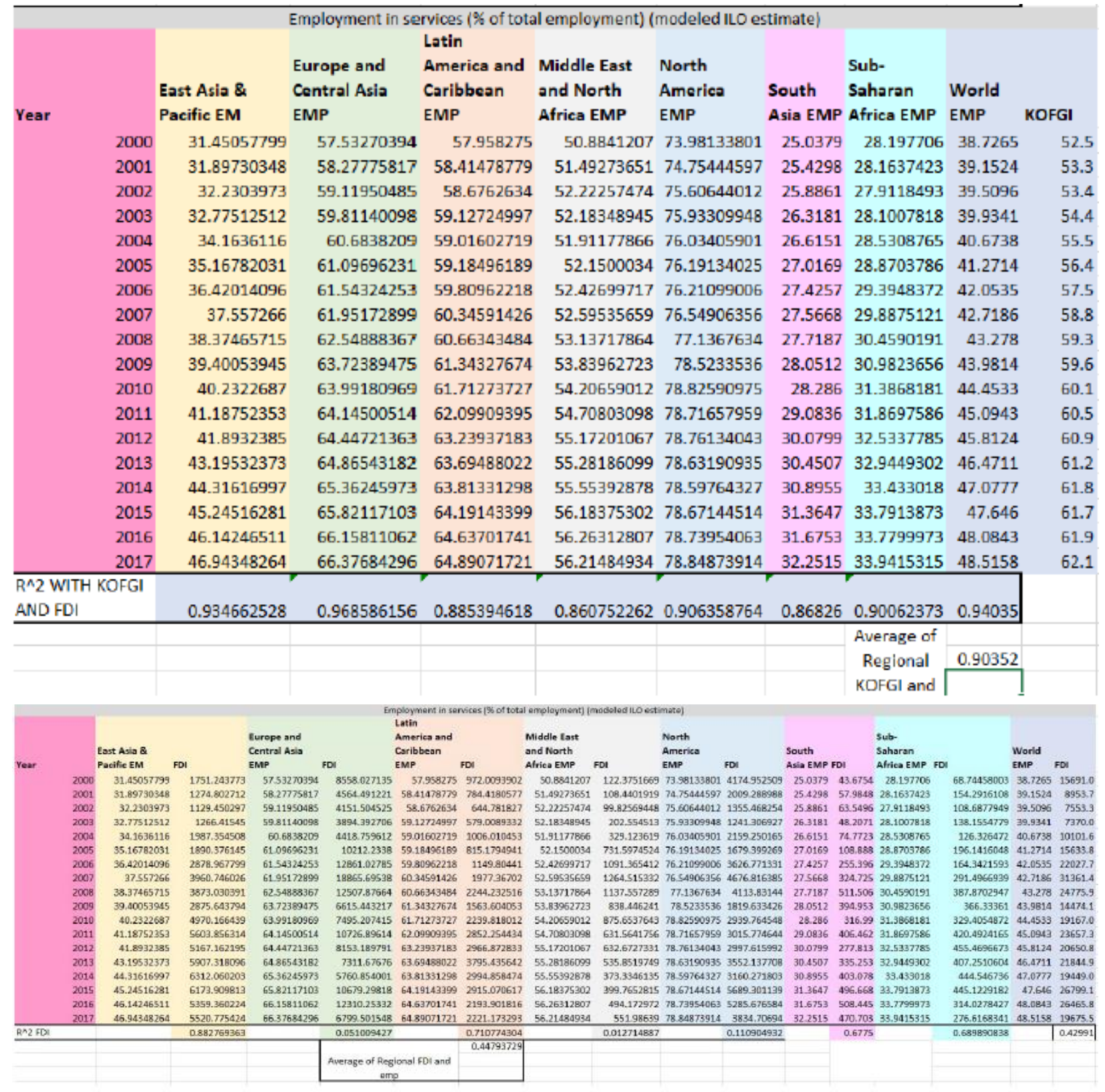

Source: World Bank 


\section{International Journal of Social Science and Economic Research}

ISSN: 2455-8834

Volume:05, Issue:10 "October 2020"

Moreover, the number of migrants has increased, and has already surpassed some 2050targeted projections. Since 1970, the number of migrants living in a country other than their birth-country have tripled. (Edmond, 202) While the population-proportion of migration has stabilized to $3.5 \%$, due to the increasing population itself, the stock of migrants has only increased. The demographic nature of migrants suggests a significant difference in the destination and immigrating countries, especially in terms of the culture of migrants' birth countries. (International Organization for Migration, 2020)

The integration of cultures occurring at an exponential pace due to technological advancements may have left human tolerance behind. Owing partly to easy access to information, and the surge of migrant population, the number of "hate-crimes" are observed to have increased substantially. (Schweppe \& Walters, 2016) Controlling for the vague international definition of hate-crimes, and a lack of international consensus of its legal proceedings, the positive relationship between globalization and migration can serve as an indication of the surge in hatecrimes.

Despite this, there has been a shift in the taboo-system of the world. There is observed a systematic de-tabooisation of what are now considered to be regressive ideals on individuals, and an emergence of new taboos of what is now considered to be infringing or offending cultures based on the offender's "superiority" complexes. (Tulnova, 2012)

Tourism has increased tremendously, owing to the increase in publicity by the nations, the influx of "influencers", decreasing travelling costs, and innovation in travelling plans. Globalisation can explain $82-87 \%$ of the increasing tourism, suggesting a positive impact. 


\section{International Journal of Social Science and Economic Research}

ISSN: $2455-8834$

Volume:05, Issue:10 "October 2020"

\begin{tabular}{|c|c|c|c|c|c|c|c|c|c|}
\hline \multicolumn{10}{|c|}{ International tourism, number of arrivals } \\
\hline YEAR & $\begin{array}{l}\text { WORLD } \\
\text { KOFGI }\end{array}$ & $\begin{array}{l}\text { WORLD } \\
\text { TOUR }\end{array}$ & $\begin{array}{l}\text { East Asia \& } \\
\text { Pacific TOUR }\end{array}$ & $\begin{array}{l}\text { Europe and } \\
\text { Central } \\
\text { AsiaTOUR }\end{array}$ & $\begin{array}{l}\text { Latin } \\
\text { America and } \\
\text { Caribbean } \\
\text { TOUR }\end{array}$ & $\begin{array}{l}\text { Middle } \\
\text { East and } \\
\text { North } \\
\text { Africa } \\
\text { TOUR }\end{array}$ & $\begin{array}{l}\text { North } \\
\text { America } \\
\text { TOUR }\end{array}$ & $\begin{array}{l}\text { South } \\
\text { Asia } \\
\text { TOuR }\end{array}$ & $\begin{array}{l}\text { Sub- } \\
\text { Saharan } \\
\text { Africa } \\
\text { TOUR }\end{array}$ \\
\hline 2000 & 52.5 & 689646049.5 & 105029882 & 389836572.5 & 55998810.83 & 39651560 & 71197000 & 4826436 & 18836377 \\
\hline 2001 & 53.3 & 690513487.8 & 110822017.9 & 390893382.8 & 54473622.94 & 39186061 & 66884000 & 4486400 & 19643063 \\
\hline 2002 & 53.4 & 711141538.3 & 119828659.6 & 402531248 & 51873754.77 & 43196920 & 63922000 & 4321774 & 21262756 \\
\hline 2003 & 54.4 & 701698868.6 & 107623996.5 & 405117127.1 & 53341735.34 & 45318135 & 59009000 & 4966540 & 22511769 \\
\hline 2004 & 55.5 & 775453106.3 & 137711392.5 & 423368713 & 59435335.99 & 53985111 & 65503000 & 6057158 & 24027247 \\
\hline 2005 & 56.4 & 823378342.6 & 148643896.2 & 446787779.2 & 64151874.83 & 57462804 & 68247000 & 6366874 & 25974009 \\
\hline 2006 & 57.5 & 869722828.7 & 160086008.3 & 468452215.1 & 66136764.36 & 63124169 & 69541000 & 7232429 & 29452662 \\
\hline 2007 & 58.8 & 934622716.6 & 177102899.1 & 494303950.2 & 68776473.34 & 71772538 & 74376000 & 8067461 & 34525586 \\
\hline 2008 & 59.3 & 950386923.4 & 175804968.9 & 496285178.6 & 71710621.52 & 81809763 & 75413000 & 8365578 & 35709661 \\
\hline 2009 & 59.6 & 911852199 & 172899870.5 & 471351413.3 & 68943481.77 & 80970591 & 71076000 & 8065426 & 33573864 \\
\hline 2010 & 60.1 & 973771581.2 & 195018784.8 & 484938945.8 & 73253699.45 & 93031790 & 76461000 & 9234491 & 36755949 \\
\hline 2011 & 60.5 & 1013076858 & 206832527.9 & 516232620.4 & 76578867.37 & 80718118 & 79727410 & 10392363 & 36693732 \\
\hline 2012 & 60.9 & 1070183029 & 221489481.3 & 541182050.8 & 79169698.21 & 89091318 & 83542900 & 10725073 & 39172281 \\
\hline 2013 & 61.2 & 1122920655 & 236156147.4 & 569249315.7 & 81239102.72 & 90609654 & 87937910 & 11682769 & 39668472 \\
\hline 2014 & 61.8 & 1177079693 & 249070596.2 & 582994926.2 & 90166653.58 & 96281878 & 92140350 & 18915333 & 41592506 \\
\hline 2015 & 61.7 & 1227873879 & 263417518.5 & 608656396.7 & 96998898.62 & 93830214 & 95964520 & 19773339 & 43494339 \\
\hline 2016 & 61.9 & 1271881627 & 283768499.4 & 621598530 & 103358519.8 & 93328132 & 96622480 & 22066208 & 45672649 \\
\hline 2017 & 62.1 & 1363216205 & 300522331.5 & 675130479 & 111174514.5 & $1 E+08$ & 98339740 & 23825233 & 47629536 \\
\hline \multirow[t]{2}{*}{$R^{\wedge} 2$} & & 0.871500823 & 0.869425469 & 0.83510678 & 0.774620583 & 0.973058 & 0.719893 & 0.647916 & 0.959304 \\
\hline & & & 0.825617636 & & & & & & \\
\hline
\end{tabular}

Source: World Bank

The decrease in travelling costs, along with an overall decrease in price of medicine has increased its overall accessibility. Improved capital, and labour mobility has also aided in innovative healthcare solutions. Affecting both the demand and supply of medicinal interventions in areas like organ transplant, cardiac surgery, cosmetic, joint, and dental procedures. However, the downside to this is there is a further propagation of unusual and resistant infections, particularly in cases of vulnerable healthcare travel. (Chen \& Wilson, 2013) Whether the increase in medical innovation can keep up with the magnitude of medicine consumed as treatment and as animal farming, however, is another issue which requires a longer timeline to be reviewed.

\section{Capital Movements}

Globalization is a process of interaction and integration among the people, companies, and governments of different nations, a process driven by international trade and investment and aided by information technology. 


\section{International Journal of Social Science and Economic Research}

ISSN: $2455-8834$

Volume:05, Issue:10 "October 2020"

A foreign direct investment (FDI) is an investment made by a firm or individual in one country into business interests located in another country. Generally, FDI takes place when an investor establishes foreign business operations or acquires foreign business assets in a foreign company.

Foreign direct investment (FDI) and globalization have a two-way relationship. They are interconnected. Not only does globalization affect foreign direct investment (FDI) but foreign direct investment (FDI) also plays an important role in showing the extent of globalization from an investment standpoint and show capital flows between select countries or globally.

After running two regressions with globalization(using the KOF globalization index) as the independent variable in both and using international foreign direct investment(FDI) inflows and foreign direct investment(FDI) outflows respectively in each we found out that the $\mathrm{R}$ square for foreign direct investment(FDI) inflow was 0.81 and for foreign direct investment(FDI) outflow was 0.77. The data analysis was done for the data from 1990-2017.

This shows that 81 percent of variability in foreign direct investment (FDI) inflow is explained by the change in the globalization index and 77 percent change in foreign direct investment (FDI) outflow is also explained by the change in the globalization index. This shows us that indeed there is a very strong relationship between foreign direct investment (FDI) and globalization.

As globalization has been increasing so has flow of information between countries. This flow of information is very important for development of foreign direct investment (FDI) in any country. All investors want to have relevant information before investing in another country. With the increase in globalization there has been increase in the availability of such information making investing overseas a better option. Similarly, with increase in foreign direct investment (FDI) there has also been an increase in such information leading to more interconnectivity and as we mentioned earlier this is the basic definition of globalization. Such information such as

tax rates, tariffs, regulations, subsidies etc. either make destination more favourable or unfavourable for investment and hence are important when make investment decisions.

Another important aspect of globalization is the actual accessibility it provides to overseas markets. Before globalization in many countries there weren't many opportunities for foreign direct investment (FDI). But with globalization increasing and interdependency between countries increasing the foreign direct investment (FDI) among countries is also on the rise. The world can be looked as a one big market place now and foreign direct investment (FDI) is almost like domestic investment and in many cases even better due to better market conditions 
in other countries.

In an open, globalized world, investment demand depends only on the existing investment potential, businesses looking for opportunities wherever they are. Since the mid-1980s, global economic integration has entered a new period. Since then international economic activities have significantly influenced the economic conditions and national economic policies. Economic distance between countries has decreased remarkably; trade has continued to grow intensively, capital movements exploded, while transfers of capital and knowledge have increased. In other words, countries have become more interdependent and the process of strong economic integration emphasized in the past 20 years. Globalization, deregulation favoured by the deregulation regarding movement of capital and opening of the countries towards market economy, manifested by diversifying forms of internationalization of production - world trade, FDI and enterprise networks.

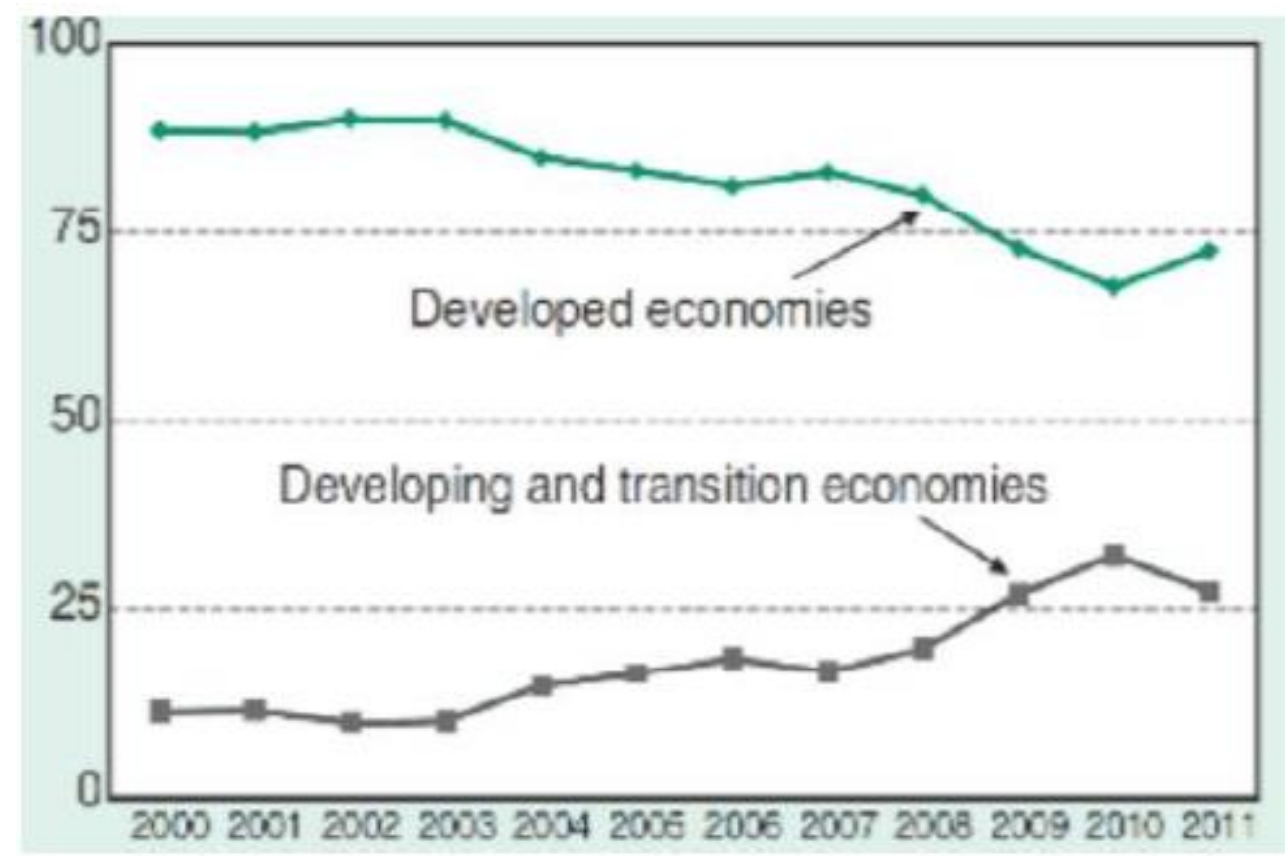

(Donciu)

This graph shows that the proportion of foreign direct investment(FDI) in developing and transition economies is also increasing and hence we can say that indeed the increase in foreign direct investment(FDI) is not only increasing in the developed countries that already were a part of the global network we can conclude that new countries are becoming a larger part of the global market and hence increasing globalization.

Over time, international trade has grown twice faster than GDP, whereas FDI flows have grown twice as fast as world trade. In the last decade, there were many causes that gave rise to the 


\section{International Journal of Social Science and Economic Research}

ISSN: $2455-8834$

Volume:05, Issue:10 "October 2020"

expansion of FDI. Among them we can mention: the international expansion of production promoted by transnational companies; the level of economic development or implementation stage of the reforms; the growing movement of capital gain generated by a large number of cross-border mergers and acquisitions; the appearance of integration formations; globalization of production and the internationalization of markets; the enhancing of technology international transfer; the differences between the efficiency and structure of markets and not least existing complementary relationship between trade and investment. (Donciu).

\section{Technological Innovation}

Globalization and innovation help the development and advancement procedure of the nation as it adds to the nation's rare and fixed assets. Since the time printing press came into existence, technological innovation/improvements directly correlate to enhance the productivity rate (Solow growth model). As countries get liberated and start trading with each other, companies all around the world become greedy to get the alpha and try to minimize the cost to stay competitive and operative. Human productivity can only evolve with the help of the tools provided. This although acts as a booster increases the inequality and dependence of one country on the other. But if followed the trend with economic progress this could also result in convergence. Although it takes time, effort, research and development and effective patent law in the country, technological advancements are the single most effective move to climb in per capita GDP.

Many arguments can made about globalisation and its impacts. One could term it as a failed experiment and the other way a blessing. But globalisation and integration are one of the reasons to start a technological change where now technology supports that same integration.

Income gaps among countries are largely explained by differences in productivity. By raising the capital/labour ratio and rapidly assimilating technologies across a wide range of activities, China for e.g. has increased factor productivity manifold since 1980 and entered the ranks of middleincome countries. China has re-asserted its objective of turning into a decently prosperous society by 2020.During the following decade, a greater amount of the increases in efficiency are probably going to get from innovation assimilation and adjustment enhanced by gradual development, while elevated levels of venture will stay a significant wellspring of development of the world through extending and epitomized technological change.

\section{Changes in labour markets}

Technological change and globalisation can create losers, but they also bring about opportunities in terms of jobs and wages for certain categories of workers. Existing jobs are furthermore destined to undergo profound change. For specialized change and globalization to profit to all, 


\section{International Journal of Social Science and Economic Research}

ISSN: $2455-8834$

Volume:05, Issue:10 "October 2020"

laborers should have the option to ace new innovations and to have the essential capabilities to exploit from the advantages that universal exchange gives. This is the thing that Jan Tinbergen named, as of now in 1974, the "race among training and innovation" (Tinbergen,1974). Right now, is fundamental to build the proficiency and value of the underlying preparing framework, yet additionally that of keeping preparing. Deep rooted realizing is the thing that empowers people to get away from abilities outdated nature, down- grading, and joblessness. The additions produced by technological change and globalization likewise should be better conveyed among laborers (more victors, less failures), to build request and in this manner advance occupation creation.

It is suggested that the spread of technical change would reduce the demand for labour of those performing routine tasks, the said workers being gradually replaced by computers and automation. In most cases, these are machine operators and office employees classified as occupying intermediate-pay occupations. Quite to the contrary, technical change is complementary to the non-routine cognitive tasks performed by highly skilled workers and very high-wage occupations. It would increase demand for them and in turn the wages in these occupations (directors, engineers, researchers). As for manual tasks, which are characterized by a combination of specific motor movements (services to individuals, construction, etc.), they are still difficult to replace by machines or computers.

\section{Exposure to international competition and local labour markets}

The analysis highlights the sectors the most exposed to the risk of offshoring (textiles/ clothing, furniture and machining and electronic equipment) and those less exposed (luxury products, chemicals, and pharmaceuticals). These results confirm that sectors that are vulnerable to the risk of offshoring are also those producing highly differentiated varieties of goods, or goods with high added value. The sectors affected by the risk of offshoring are those with activities intensive in routine tasks. Globalisation would thus reinforce the negative effects of technical change on routine jobs.

\section{Impact of international trade on employment and its structure}

The examination of Biscourp and Kramarz (2007), did at the degree of organizations situated in France, shows that opposition from imports is explicitly connected with the annihilation of creation employments, and particularly that of untalented specialists. Specifically, the import of completed items, a sign of remote offshoring of all or part of neighbourhood creation, most unmistakably goes with the decrease in relative interest in untalented business. Harrigan et al. (2016) affirm this outcome in an examination of a later period. 


\section{International Journal of Social Science and Economic Research}

ISSN: 2455-8834

Volume:05, Issue:10 "October 2020"

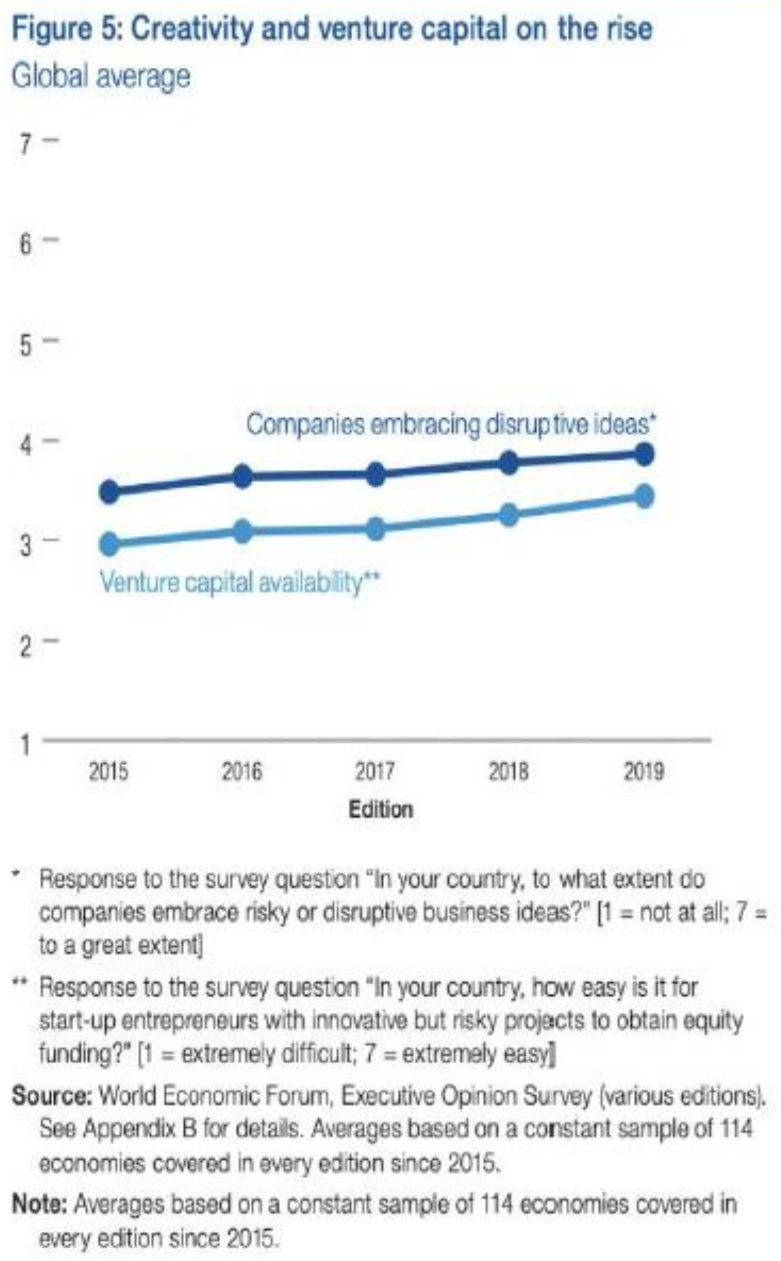

Figure 6: Technology governance

"In your country, how fast is the legal framework adapting to digital business models (e.g., e-commerce, sharing economy, FinTech, etc.)?" [1 = not fast at all; 7 = very fast $]$.

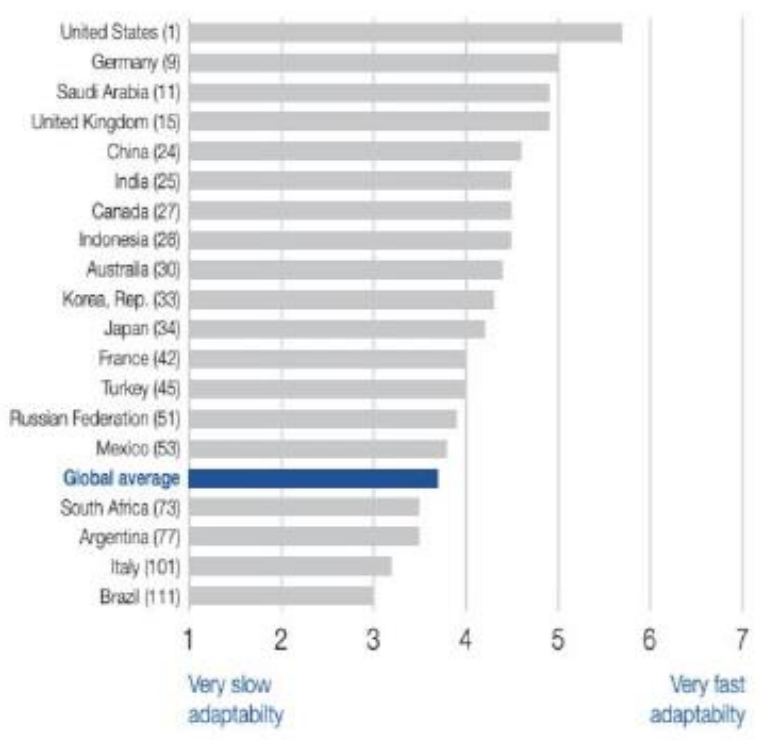

Source: World Economic Forum, Executive Opinion Survey (various editions). See Appendix B for details.

Note: Rank out of 141 in parentheses.

In most advanced and emerging economies, technology adoption and innovation have become priorities for governments and companies alike as a source of value creation, productivity growth and improved living standards. Technology can also improve access to basic services, working conditions, health outcomes and economic security. The GCI 2019 results show that, globally, more companies are embracing disruptive ideas and availability of venture capital is on the rise. (see Figure 5). However, despite these efforts, the results also reveal there is a lot of scope to do better in both adopting technology and boosting innovation. Only four economies score above 80 on the Innovation capability pillar-Germany, United States, Switzerland, and Taiwan (China) — and only one-quarter score above 50. Globally, the median score is just 38 .

The life of an innovation, through the research and development process, to a marketable product, and onto the widespread diffusion across frontiers, is essentially international. This will bring about better administration and coordination between globalization. 
International Journal of Social Science and Economic Research

ISSN: 2455-8834

Volume:05, Issue:10 "October 2020"

\section{Conclusion}

The pace at which globalization occurs is akin to that of creative destruction in any innovation. (Cowen, 2002) With that in mind, one must also consider that with each wave of innovation, the time-spread of it reduces, and the impact of the wave in that shortening timeperiod only increases.

Globalization is no longer a zero-sum game. With the advancement of technology, even the most under-developed of regions are picking up their growth-pace, albeit at one slower than their richer counterparts. Globalization also does not have only positives, which can be seen from the existence of widening within-country inequalities, racial tensions, volatility in capital flow, and stagnant real-income growth.

Despite this, we see a stabilising migration population proportion, strides in sustainable development, reduction in between-country inequalities, reduction of poverty, increased accessibility of healthcare, increasing standards of living, innovation, and technological advancement.

The Fourth Wave of Globalization has been unlike the previous ones seen before. It is augmenting a new sector of employment, shouldering a scale of technological innovation never seen before, and enduring the most of a new wave of protectionism, while keeping in mind the original aspects of globalisation vis-à-vis trade, poverty, and inequality. This time, the pressing impact of climate change also hinders the growth of globalization, which was previously largely dependent on the exploitation of natural resources.

\section{References}

Adler, Gustavo, Romain Duval, Davide Furceri, Sinem Kilic Celik, Ksenia Koloskova and Marcos Poplawski-Ribeiro, "Gone with the Headwinds: Global Productivity", IMF Staff Discussion Note No. 17/04, International Monetary Fund (IMF), 2017.

Bank, T. W. (n.d.). World Bank Open Data. Retrieved from The World Bank: https://data.worldbank.org/

Bebczuk, R., \& Gasparini, L. (2001). Globalisation and Inequality. The Case of Argentina Biscourp, P. \& Kramarz, F. (2007). Employment, skill structure and international trade: Firmlevel evidence for France. Journal of International Economics, 72(1), 22-51

Chen, L. H., \& Wilson, M. E. (2013). The Globalization of Healthcare: Implications of 
International Journal of Social Science and Economic Research

ISSN: 2455-8834

Volume:05, Issue:10 "October 2020"

Medical Tourism for the Infectious Disease Clinician. Clinical Infectious Diseases, 17521759.

Cowen, T. (2002). Creative Destruction: How Globalization Is Changing the World's Cultures. Princeton University Press.

Donciu, E. C. (n.d.). GLOBALIZATION AND FOREIGN DIRECT INVESTMENTS. Retrieved from core.ac.uk: https://core.ac.uk/download/pdf/27162538.pdf

Dreher, A. (2006). Does globalization affect growth? Evidence from a new index of globalization. Applied Economics, 1091-1110.

Edmond, C. (202, January 10). Global Migration, by The Numbers: Who Migrates, Where They Go and Why. Retrieved from World Economic Forum:

weforum.org/agenda/2020/01/iom-global-migration-report-international-migrants- 2020/

Esteban Ortiz-Ospina, D. B. (2014, May 3). Globalisation and Trade. Retrieved from Our world In Data: https://ourworldindata.org/trade-and-globalization

Gygli, S., Haelg, F., Potrafke, N., \& Sturm, J.-E. (2019). The KOF Globalisation Indexrevisited. The Review of International Organizations, 543-574.

Harrison, A. (2006). Globalisation and poverty.

Heekyong Yang, J.-m. P. (2019, august 1). South Korean chip giants face 'strangling'from Japanese export curbs. Retrieved from reuters.com:https://www.reuters.com/article/ussouthkorea-japan-laborers-chip-analys/south- korean-chip-giants-face-strangling-fromjapanese-export-curbs-idUSKCN1UR3LZ

Ho, H.-J. (2019, January 28). WEF2019: What Is Globalisation 4.0? Retrieved from Finance Monthly: https:/www.finance-monthly.com/2019/01/wef2019-what-is-globalisation- 4-0/

Joe Hasell, S. M. (n.d.). Recent trends in income inequality. Retrieved from http://publications.iarc.fr/_publications/media/download/5750/c7acdf85e530699d07b $\underline{\text { 8faf775710528411f66ce.pdf }}$

IMF. (2007). Globalization and Inequality.

Retrieved from https://www.imf.org/ /media/Websites/IMF/imported-flagshipissues/external/pubs/ft/weo/2007/02/pdf/_c4pdf.ashx 
International Journal of Social Science and Economic Research

ISSN: 2455-8834

Volume:05, Issue:10 "October 2020"

Income Inequality: A Global Perspective.

Retrieved from imf.org: https://www.imf.org/external/pubs/ft/sdn/2015/sdn1513.pdf

International Organization for Migration. (2020). World Migration Report 2020.

Pilger, J. (2001). The New Rulers Of The World.

Romano, D., \& Yotpoulos, P. (2007). The Asymmetries of Globalization.

Rose, A. K. (2015). why countries with a positive global influence export more. World Economic Forum.

Schweppe, J., \& Walters, M. A. (2016). The Globalization of Hate: Internationalizing Hate Crime? . Oxford University Press.

Strauss, K. (2017, march 27). Made In Where? The Countries With The Best Reputations For Producing Quality. Retrieved from Forbes.com:

https://www.forbes.com/sites/karstenstrauss/2017/03/27/made-in-where-the- countries-withthe-best-reputation-for-producing-quality/\#3bbb64c84b3d

Susan Lund, J. M. (2019, January 1). Globalization in transition: The future of trade and value chains. Retrieved from mckinsey.com: https://www.mckinsey.com/featuredinsights/innovation-and-growth/globalization-in-transition-the-future-of-trade-and- value-chains

The World Commission on the Social Dimension of Globalization. (2004, February 24). The Social Dimension of Globalization. Retrieved from International Labour Organization: https://www.ilo.org/public/english/wcsdg/globali/index.htm

Tulnova, M. (2012, March). Taboo in the Context of Globalization. Retrieved from Scientific publications of the Humanities and Social Sciences University of Lille: https://hal.univlille3.fr/hal-00840674

UNDP. (n.d.). Income inequality. Retrieved from https://www.undp.org/content/dam/undp/library/Poverty\%20Reduction/Inclusive $\% 20$ development/Humanity\%20Divided/HumanityDivided_Ch3_low.pdf

Wade, R. H. (2004, July 1). Is Globalization Reducing Poverty and Inequality?

World Economic Forum. (2019). The Global Competitiveness Report. Geneva: World Economic Forum. 
International Journal of Social Science and Economic Research

ISSN: 2455-8834

Volume:05, Issue:10 "October 2020"

World Inequality Database (2018). WHAT IS THE AIM OF THE WORLD INEQUALITY

REPORT2018? Retrieved from https://wir2018.wid.world/executive-summary.html 